\title{
Machado de Assis: do teatro. Textos críticos e escritos diversos \\ de João Roberto Faria \\ São Paulo, Perspectiva, 2008.
}

\author{
Elizabeth R. Azevedo
}

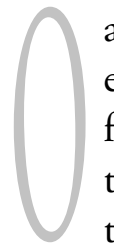

ano 2008 foi marcado por inúmeros eventos comemorativos ao centenário de falecimento de Machado de Assis. Em setembro, o pesquisador e professor de $\mathrm{Li}$ teratura Brasileira da USP, João Roberto Faria, lançou seu mais recente trabalho: Machado de Assis: do teatro. Textos críticos e escritos diversos, 679 páginas, pela editora Perspectiva ${ }^{1}$. Independente da efeméride, a obra já surge como referência fundamental nos estudos machadianos e do teatro brasileiro. Composta de duas partes distintas, apresenta inicialmente uma análise da trajetória percorrida por Machado como crítico teatral, especificamente, ou como folhetinista sempre interessado nos acontecimentos dos palcos cariocas entre os anos de 1856 e 1908. No restante do volume (a maior parte dele), colige e edita cuidadosamente as matérias publicadas nos diferentes órgãos de impressa com os quais Machado colaborou ao longo de sua carreira de jornalista.

As análises do professor João Roberto são sempre no sentido de realçar o diálogo entre o pensamento de Machado e o meio teatral brasileiro com o qual conviveu. Essa tarefa desem- boca em comentários de clareza e justeza lapidares na medida em que o autor é profundo conhecedor do período e já estudara em trabalhos precedentes a obra dramática de José de Alencar, o estabelecimento do teatro realista no Brasil, a rarefeita presença do teatro naturalista entre nós e, numa pesquisa de grande fôlego similar a que apresenta agora, realizou a compilação do pensamento teórico teatral brasileiro no século XIX. É portanto com muita propriedade que destaca desse contexto maior a figura daquele que é considerado um dos melhores críticos teatrais brasileiros.

Inicialmente, são apresentadas as premissas e convicçôes do jovem crítico (nacionalismo, moralismo, engajamento, isenção crítica muito próximo ao que propunha seu amigo Quintino Bocaiúva), passando pela revisão de certas posições até chegar ao desalento expresso no desiludido comentarista maduro. O estudo começa ressaltando como Machado se empenhou na luta pela renovação do teatro nacional em meados do século, apoiando iniciativas que procuravam trazer para o Brasil a estética realista, tanto na dramaturgia quanto na encenação,

Elizabeth R. Azevedo é professora do Departamento de Artes Cênicas e do Programa de Pós-Graduação em Artes Cências da ECA-USP.

1 Assis, Machado de. Machado de Assis: do teatro. Textos críticos e escritos diversos. São Paulo: Perspectiva, 2008. 
não se furtando a criticar o consagrado ator João Caetano, representante maior da antiga escola. Isso porque Machado foi um crítico completo, que abriu espaço para a análise de cada elemento componente da obra, desde o texto até a interpretação e a encenação (limitada pelos padrôes da época a questôes acerca da adequação de cenários, figurinos e, eventualmente, música). Dedicava-se também a avaliar, criticar e sugerir mudanças na prática empresarial que regia a lógica das apresentações. Apesar de ter mudado de opinião sobre outros assuntos, nunca abandonou a idéia de que o teatro, assim como as outras artes, deveria ser apoiado pelos poderes públicos. Essa posição concatenava-se com sua crença, também perene, de que o teatro é uma escola de moralidade e aprimoramento social, na qual o público pode se aperfeiçoar constantemente. Apesar de ter mantido essa convicção até o fim da vida (motivo pelo qual se desiludiu profundamente com os rumos do teatro nacional no final do século XIX, diante do irreprimível sucesso do chamado teatro ligeiro), a premissa sobre a qual a fundamentava mudara alguns anos depois de ter começado a atuar como crítico. O professor João Roberto aponta a leitura dos escritos de Mme. de Stäel como responsável por essa guinada. Na verdade, Machado ampliou seu conceito de moralidade, não mais o restringindo ao ideário burguês, mas incorporando a idéia de que "uma obra é moral se a impressão que se recebe é favorável ao aperfeiçoamento da alma humana. [...] A moralidade de uma obra consiste nos sentimentos que ela inspira"2 como sugerido pela autora francesa que tanta influência tivera sobre o romantismo. A partir daí, Machado parece mais tranqüilo para afirmar que não só a estética moderna (realista e "utili- tária”) o agradava, mas também toda aquela de qualidade estética e artística inegável.

Entre outras coisas, é importante chamar a atenção para a apreciação do efeito que tiveram também sobre Machado as atuações dos grandes atores europeus presentes no Rio em suas temporadas no Brasil. Destaque-se a indelével marca deixada por Ernesto Rossi, sobretudo em suas interpretaçôes de Shakespeare. Apesar de conhecer muito bem a obra escrita do dramaturgo inglês, ter visto as boas encenações desses textos pelo consagrado ator italiano propiciou a Machado uma maior percepção da profundidade no desenho dos personagens. E teria sido essa profundidade, essa universalidade chamada de desenho da alma que ele, tão nacionalista a princípio, passou a buscar em suas próprias criaturas. “(...) Shakespeare no palco foi uma revelação para Machado (...) a partir desse ano [1871] torna-o um constante interlocutor (...)".3

Por que tal profundidade foi conseguida mais em seus romances e contos do que nas peças não é possível discutir aqui. O que importa é notar como a vivência teatral foi importante na formação do grande escritor.

Por outro lado, o livro não deixa de apontar as atitudes de Machado que poderiam ser consideradas hoje como preconceituosas ou autoritárias, como sua atuação como censor do Conservatório Dramático Nacional e sua reivindicação de um poder ainda maior para a entidade, a qual deveria poder proibir peças de baixo valor artístico; ou a constante crítica que fez aos gêneros do teatro musicado, à farsa burlesca e à sátira. Contudo, tais convicções do crítico são apresentadas à luz do século e apreendidas como parte da opiniáo corrente no ambiente intelectual nacional.

\footnotetext{
Idem, p. 69.

3 Idem, p. 86.
} 
Na segunda parte do livro, arrolam-se as críticas e os folhetins existentes nos acervos nacionais, ampliando o número de textos já conhecidos nas, assim chamadas, "obras completas" de Machado de Assis. O cuidado e o respeito na reprodução do material expressam-se em notas de rodapé que justificam e esclarecem os partidos adotados, bem como na manutenção da integridade dos textos e mesmo da pon- tuação (imagine-se o quanto deve ter lutado com o programa do computador ao preservar as vírgulas que separam sujeito e predicado!).

Então, a partir de agora, podemos contar com uma obra de mérito inegável que facilita o acesso à documentação e permite a apreciação da contribuição de Machado tanto para a história das idéias teatrais como para a crítica no Brasil. 